\title{
Robert Kurek
}

Uniwersytet Ekonomiczny we Wrocławiu

e-mail: robert.kurek@ue.wroc.pl

\section{ROLA RAD NADZORCZYCH I KOMITETÓW AUDYTU W KONTEKŚCIE OBOWIĄZKÓW INFORMACYJNYCH JEDNOSTEK ZAINTERESOWANIA PUBLICZNEGO THE ROLE OF SUPERVISORY BOARDS AND AUDIT COMMITTEES IN THE CONTEXT OF INFORMATION OBLIGATIONS OF PUBLIC INTEREST ENTITIES}

DOI: 10.15611/pn.2018.531.25

JEL Classification: G34, K22, L22, M41

Streszczenie: W spółkach kapitałowych (ksh) obowiązek nadzorowania i monitorowania procesu sporządzania i badania sprawozdań finansowych realizowany jest przez rady nadzorcze. W przypadku gdy spółka ma status jednostki zainteresowania publicznego (JZP), tworzone jest dodatkowe ciało, jakim jest komitet audytu. Porównanie kompetencji obu organów pozwala na stwierdzenie, że ich zadania i obowiązki się powielają. Jednak zgodnie z polskim prawem jedynie rada nadzorcza jako całość ma wyłączne, ustawowe kompetencje decyzyjne. Komitet nie może zatem zastępować rady, zaś jego funkcja ogranicza się do działalności doradczej i wspierającej działalność rady. Jednak dzięki niezależności i określeniu kwalifikacji członków komitetu, przewidywanym karom administracyjnym oraz enumeratywnie wymienionym kompetencjom i obowiązkom możliwy jest pełniejszy nadzór nad adekwatnością i skutecznością wszelkich systemów spółki w kontekście prawidłowości i rzetelności generowanych informacji, a tym samym wspomaganie bezpiecznego funkcjonowania JZP.

Slowa kluczowe: komitet audytu, rada nadzorcza, obowiązki informacyjne.

Summary: In capital companies (CC) the obligation to supervise and monitor the process of preparing and auditing financial statements is carried out by the supervisory boards. If a company has the status of a public interest entity (PIE), an additional body is established, i.e. the audit committee. Comparing the competences of both bodies allows stating that their tasks and obligations are duplicated. However, in accordance with Polish law only the supervisory board, as a whole, has the exclusive, statutory decision-making powers. Therefore, the committee cannot replace the council, whereas its function is limited to advisory and supportive activities provided for the council. Independence and qualifications of the committee members, anticipated administrative fines and enumerated competences allow for the supervision over both adequacy and effectiveness of all systems in the context of the correctness and reliability of the generated information, and thus support the safe functioning.

Keywords: audit committee, board of directors, information obligations. 


\section{Wstęp}

Od 21 czerwca 2017 r. obowiązuje Ustawa z dnia 11 maja 2017 r. o biegłych rewidentach, firmach audytorskich oraz nadzorze publicznym, która wprowadziła istotne zmiany w zakresie składu i funkcjonowania rad nadzorczych i komitetów audytu, a także w zakresie kompetencji członków tych organów w jednostkach zainteresowania publicznego (JZP).

Celem artykułu jest skonfrontowanie zadań i roli członków zarówno rad nadzorczych, jak i komitetów audytu w świetle nałożonych na te organy obowiązków w zakresie monitorowania oraz nadzorowania procesu generowania i badania sprawozdań finansowych. Postawiona na wstępie teza brzmi, że obowiązki te się powielają i nakładają, przez co nie zmieniają w istotny sposób zakresu monitorowania i nadzoru nad obowiązkami informacyjnymi nałożonymi na jednostki zainteresowania publicznego.

Badania mają charakter opisowy i wyjaśniający, bowiem ze względu na swój subiektywny charakter wszelkie rozważania dotyczące roli (znaczenia) określonych podmiotów w procesie nadzorowania zawsze pozostaną przedmiotem badań na poziomie ekonomii normatywnej. W procesie badawczym zostały zebrane, przeanalizowane oraz zinterpretowane informacje źródłowe (literatura przedmiotu, regulacje prawne), które wraz z własnymi refleksjami i doświadczeniami autora oraz po zapoznaniu się z mechanizmami dotyczącymi funkcjonowania rad nadzorczych i komitetów audytu posłużyły do zweryfikowania postawionej tezy.

\section{Rada nadzorcza a nadzór nad obowiązkami informacyjnymi spółki}

Rozdział kompetencji organów spółki określony w kodeksie spółek handlowych precyzuje, że rada nadzorcza jest kolegialnym organem spółki powołanym do sprawowania stałego nadzoru, realizowanego na wielu płaszczyznach, we wszystkich dziedzinach działalności spółki [Ustawa z 15 września 2000], a jedną z tych płaszczyzn jest kontrola rachunkowa [Sołtysiński i in. 2008, s. 750]. W jej ramach rada nadzorcza ocenia sprawozdania finansowe spółki oraz wnioski zarządu w przedmiocie podziału zysku albo pokrycia straty [Ustawa z 15 września 2000, art. $382 \S$ 2]. Ocena sprawozdań finansowych przez radę nadzorczą dokonywana jest zarówno pod kątem ich zgodności z treścią dokumentów spółki, jak i ze stanem faktycznym. Sprawując kontrolę rachunkową, rada nadzorcza - jako całość - ma również obowiązek przedkładać walnemu zgromadzeniu coroczne pisemne sprawozdanie z przeprowadzonej oceny sprawozdań finansowych [Ustawa z 15 września 2000, art. 382 § 3] oraz ma obowiązek zapewnić, aby sprawozdania finansowe spółki i sprawozdania $z$ działalności spełniały wymogi przewidziane w ustawie o rachunkowości [Ustawa z 29 września 1994], a za należyte sporządzenie sprawozdań wymaganych przepisami tej ustawy ponosi odpowiedzialność wspólnie z zarządem 
[Walińska, Gad 2012, s. 206-207]. Za nienależyte wykonanie powierzonych radzie nadzorczej zadań ustawodawca wprowadził szereg sankcji, które mogą mieć charakter korporacyjny, cywilny bądź karny [Grzybek 2018].

Działanie w interesie spółki (i jej właścicieli) zobowiązuje radę nadzorczą do weryfikacji procesu rzetelnego i jasnego przedstawiania sytuacji majątkowej i finansowej spółki oraz jej wyniku finansowego, dlatego też rada nadzorcza powinna na bieżąco kontrolować przygotowywanie sprawozdań finansowych oraz czuwać nad tym, aby wybrany przez spółkę niezależny audytor był osobą kompetentną i rzetelnie wykonywał swoje obowiązki.

Kodeks spółek handlowych nie wyklucza możliwości powołania innego, wewnętrznego organu spółki, któremu mogą być powierzone uprawnienia o charakterze rewizyjnym lub nadzorczym (podmiot doradczy, zobowiązany do przygotowywania projektów stanowisk rady itd.). Takim organem, powołanym na mocy przepisów zewnętrznych (a nie statutu spółki), jest komitet audytu, którego nowy kształt zadań i obowiązków dla jednostek zainteresowania publicznego określony został w ustawie o biegłych rewidentach, firmach audytorskich oraz nadzorze publicznym [Ustawa z 11 maja 2017].

\section{Komitety audytu - zasady funkcjonowania w nowym ujęciu prawnym}

Ustawa o biegłych rewidentach, firmach audytorskich oraz nadzorze publicznym [Ustawa z 11 maja 2017] dostosowała polskie prawo do przepisów dwóch unijnych aktów prawnych: dyrektywy w sprawie ustawowych badań rocznych sprawozdań finansowych i skonsolidowanych sprawozdań finansowych [Dyrektywa z 16 kwietnia 2014] oraz rozporządzenia w sprawie szczegółowych wymogów dotyczących ustawowych badań sprawozdań finansowych jednostek interesu publicznego [Rozporządzenie z 16 kwietnia 2014].

Nowa regulacja założyła, że komitety audytu mają działać praktycznie w każdej spółce posiadającej status jednostki zainteresowania publicznego. Do podmiotów, które posiadają status JZP, należą głównie spółki giełdowe, a także wiele jednostek sektora finansowego (m.in. banki, otwarte fundusze emerytalne, zakłady ubezpieczeń i zakłady reasekuracji, otwarte fundusze inwestycyjne itd.) $)^{1}$.

Członkowie komitetu audytu wybierani są spośród członków rady nadzorczej, jednakże muszą oni spełniać określone kryteria ${ }^{2}$. Jednym z podstawowych jest nie-

\footnotetext{
1 Jedynie w spółkach giełdowych z sektora MŚP możliwe jest pełnienie funkcji komitetu audytu przez radę nadzorczą, natomiast do czasów wejścia w życie nowej ustawy w przypadku 5-osobowych rad nadzorczych możliwe było powierzenie funkcji komitetu audytu radzie nadzorczej, co było często praktykowane [Mikulski 2017].

2 Nie jest to oczywiście czymś nowym. Na całym świecie od początku istnienia regulacji ustanawiających komitety audytu (ew. komisji ds. audytu) na członków nakładane były określone wymogi co do ich kwalifikacji i predyspozycji [Marcinkowska 2004, s. 365-386].
} 
zależność, opisana szerokim katalogiem uwarunkowań, które członkowie rady nadzorczej powinni spełniać na potrzeby pełnienia funkcji członków komitetu audytu [Ustawa z 11 maja 2017, art. 129]. Wzrost znaczenia niezależnych członków rady nadzorczej przejawia się także zapisami, z których wynika, że większość członków komitetu (składającego się z min. 3 członków) mają tworzyć członkowie niezależni, łącznie z jego przewodniczącym [Ustawa z 11 maja 2017, art. 129 ust. 1]. Ponadto doprecyzowane zostały zapisy dotyczące wymogu posiadania kwalifikacji w dziedzinie rachunkowości lub rewizji finansowej - w komitecie audytu przynajmniej jeden członek powinien je posiadać, jednak nie musi to być koniecznie członek niezależny. Dodatkowo wprowadzony został wymóg, by członkowie komitetu posiadali określony stopień wiedzy i umiejętności z zakresu branży, w której dana spółka działa [Ustawa z 11 maja 2017, art. 129 ust. 5].

\section{Komitety audytu - zadania i obowiązki}

Komitet audytu ma na celu „wspieranie odpowiedzialnego ujawniania informacji finansowych oraz czynnego, uczestniczącego nadzoru" [Report and Recommendations... 1999, s. 7], a jego najważniejszym zadaniem jest nadzór nad spójnością procesu sprawozdawczości finansowej [Dobija i in. 2011, s. 39]. Obowiązki komitetu audytu określone ustawą nie pozostawiają wątpliwości co do funkcji i zakresu kompetencji tego organu. Do zadań komitetu audytu należą w szczególności [Ustawa z 11 maja 2017]:

- monitorowanie procesu sprawozdawczości finansowej, skuteczności systemów kontroli wewnętrznej i systemów zarządzania ryzykiem oraz audytu wewnętrznego i wykonywania czynności rewizji finansowej;

- kontrola niezależności biegłego rewidenta i firmy audytorskiej;

- informowanie rady nadzorczej o wynikach badania i wskazywanie roli komitetu audytu w zakresie badania;

- ocena niezależności biegłego rewidenta oraz wyrażanie zgody na świadczenie przez niego usług innych niż badanie;

- opracowywanie polityki wyboru firmy audytorskiej do przeprowadzania badania;

- opracowywanie polityki świadczenia przez firmę audytorską przeprowadzającą badanie dozwolonych usług niebędących badaniem;

- określanie procedury wyboru firmy audytorskiej;

- przedstawianie radzie nadzorczej rekomendacji dotyczącej powołania biegłych rewidentów lub firm audytorskich;

- przedkładanie zaleceń mających na celu zapewnienie rzetelności procesu sprawozdawczości finansowej w spółce.

W kontekście obowiązków informacyjnych nałożonych na JZP oraz rzetelności generowanych informacji i zapewnienia wiarygodnej sprawozdawczości finansowej najważniejszym zadaniem komitetu audytu jest monitorowanie procesów sprawo- 
zdawczości finansowej. Oprócz zadań związanych z nadzorowaniem pracy audytorów wewnętrznych i biegłych rewidentów nowy wymiar zyskały także obowiązki związane z koordynowaniem ich prac i oceną dodatkowych sprawozdań sporządzanych przez niezależnych audytorów tylko dla komitetów audytu [Gad 2016, s. 670-671]. Komitety muszą przy tym analizować metody badania sprawozdań finansowych stosowane przez audy torów oraz oceniać, czy zastosowany w badaniu poziom istotności jest wystarczający dla pełnego uwiarygodnienia sprawozdania finansowego.

\section{Rady nadzorcze a komitety audytu - monitorowanie i nadzorowanie obowiązków informacyjnych}

Kwestia wyodrębnienia komitetów audytu zrodziła się w anglosaskim systemie nadzoru korporacyjnego, gdzie obowiązującym rozwiązaniem pozostaje rada dyrektorów, w której skład wchodzą zarówno dyrektorzy wykonawczy (zarządzający spółką), jak i dyrektorzy niewykonawczy (pełniący funkcje nadzorcze). Wobec ścisłego powiązania osób zasiadających w jednym organie $\mathrm{i}$ wynikających $\mathrm{z}$ tego tytułu silnych związków personalnych pomiędzy członkami rady dyrektorów spostrzeżono konieczność powołania takiego organu, który zachowując niezależność, będzie w stanie rzetelnie badać i nadzorować sprawozdawczość finansową spółki [Koziorowski 2017]. Instytucję komitetu audytu implementowano także do systemów prawnych, w których nadzór jest całkowicie odseparowany od zarządzania, jednak utworzenie komitetów audytu nie miało na celu wyłączenia żadnych spraw z zakresu obowiązków rad nadzorczych, które zachowały pełną odpowiedzialność za decyzje podejmowane w sferze ich kompetencji. $\mathrm{Z}$ założenia komitety audytu wzmacniają nadzór i kontrolę rad nadzorczych nad spółką ${ }^{3}$. Najważniejszym zadaniem jest przy tym monitorowanie i nadzorowanie procesów sprawozdawczości finansowej, na co składają się działania obejmujące przegląd sprawozdań finansowych i innych ujawnionych informacji, ocena zgodności sprawozdań ze stanem faktycznym, ocena jakości wykazanych zysków oraz ocena ryzyka sfałszowania sprawozdań finansowych [Bednarek 2009, s. 51].

Rzetelna realizacja obowiązków informacyjnych nałożonych na JZP i wpływ na jakość generowanych informacji oraz zapewnienie wiarygodności przedkładanej interesariuszom sprawozdawczości finansowej stały się możliwe dzięki zapisom w nowej ustawie, które:

- kazuistycznie statuują zasady organizacji i funkcjonowania komitetu audytu w jednostkach zainteresowania publicznego,

- doprecyzowały zasady niezależności członków komitetu audytu, a także podniosły kompetencje komitetów poprzez zwiększenie wymogów w zakresie kwalifikacji osób w nich zasiadających,

3 Z badań przeprowadzonych w Polsce wynika, że funkcjonowanie komitetów audytu dalekie było od założeń i zadań, jakie im zostały postawione (szerzej: [Dobija 2010, s. 5-23]). 
- zwiększyły zakres obowiązków i zadań nałożonych na członków komitetów, w tym w zakresie odpowiedniego ukształtowania sposobu wyboru biegłego rewidenta $\mathrm{w}$ danej spółce (komitety audytu zobligowane są do opracowania polityki i procedury wyboru firmy audytorskiej oraz polityki świadczenia usług innych niż badanie sprawozdań przez wybraną firmę audytorską),

- zwiększyły odpowiedzialność członków i wprowadziły katalog kar administracyjnych, które KNF może zastosować w przypadku m.in. naruszenia przepisów dotyczących powołania, składu i funkcjonowania komitetu audytu ${ }^{4}$.

Wskutek włączenia do systemu nadzoru i monitorowania procesu generowania i badania sprawozdań finansowych nowych zadań przypisanych komitetowi audytu struktura tego systemu stała się złożona i wielopoziomowa. Nie zawsze jednak wszystkie kompetencje są jasno określone, a niektóre powinności się powielają i dubluje odpowiedzialność, przykłady czego zostały poniżej wymienione:

- oceny sprawozdań finansowych i wyników badania niezależnego audytora dokonuje komitet audytu (obowiązki wynikające z ustawy o biegłych rewidentach), natomiast rada nadzorcza jest odpowiedzialna za nadzór nad sprawozdawczością finansową (sprawuje kontrolę rachunkową), a więc dokonuje oceny sprawozdań finansowych i wyników badania niezależnego audytora (obowiązki wynikające z ksh),

- rekomendacja komitetu audytu w zakresie wyboru firmy audytorskiej nie jest dla rady nadzorczej wiążąca, jednak jeśli decyzja organu dokonującego wyboru w zakresie wyboru firmy audytorskiej odbiega od rekomendacji komitetu audytu, organ dokonujący wyboru uzasadnia przyczyny niezastosowania się do rekomendacji komitetu audytu oraz przekazuje takie uzasadnienie do wiadomości organu zatwierdzającego sprawozdanie finansowe,

- odpowiedzialność za nienależyte wywiązywanie się ze swoich zadań w zakresie nadzoru nad realizacją obowiązków informacyjnych przewidziana jest zarówno w kodeksie spółek handlowych, jak i ustawie o biegłych rewidentach, przy czym wątpliwości budzi zakres odpowiedzialności członków rady nadzorczej niezasiadających w komitecie audytu [Koziorowski 2017].

Pomimo powielania się i dublowania zakresu obowiązków i odpowiedzialności wprowadzenie dla JZP obowiązku tworzenia komitetów audytu ma swoje gospodarcze i społeczne uzasadnienie - zwiększa bezpieczeństwo obrotu oraz poprawia rzetelność i prawidłowość sprawozdań finansowych, których jakość wpływa na przyszłą ocenę spółki przez wewnętrznych i zewnętrznych interesariuszy [Fila

${ }^{4}$ Kary pieniężne możliwe do nałożenia na JZP (do 10\% przychodów) lub członków komitetów audytu (do wysokości 250000 złotych lub zakaz pełnienia funkcji członka zarządu lub rady nadzorczej przez okres do trzech lat) przewidziane zostały z tytułu uchybień, do których należy m.in.: brak polityki w zakresie wyboru firmy audytorskiej, nieprzestrzeganie przepisów dotyczących: wyboru firmy audytorskiej, procedury wyboru firmy audytorskiej, obowiązków związanych z rotacją firmy audytorskiej badającej sprawozdanie finansowe, powołania, składu i funkcjonowania komitetu audytu lub w przypadku „wywierania wpływu na wynik badania”. 
2009]. W kontekście nadzorowania obowiązków informacyjnych nie jest jednak możliwa obiektywna ocena efektywności funkcjonowania komitetu audytu [Sawicki 2012, s. 165-177], bowiem bez jego powołania, określenia uprawnień i nałożenia stosownych zadań w obszarze nadzoru nad realizacją obowiązków informacyjnych generowanych przez JZP wszystkie te zadania i tak pozostałyby w gestii rady nadzorczej. I pozostają w jej gestii, bez względu na to, czy komitet audytu zostaje powołany, czy też nie (w przypadku gdy spółki nie mają statusu JZP). Zatem można by nawet wysunąć przypuszczenie, że komitety audytu nie są konieczne do właściwego nadzorowania realizacji obowiązków informacyjnych. Jednak dzięki utworzeniu komitetu audytu bieżące monitorowanie sprawozdawczości finansowej, nadzór nad istniejącymi mechanizmami kontroli wewnętrznej, audytu wewnętrznego i funkcją zarządzania ryzykiem, zapewnienie niezależności i obiektywizmu audytorów zewnętrznych stają się kluczowe dla spójności nadzoru nad procesem sprawozdawczości finansowej. Sprawnie funkcjonujący komitet audytu pozwala także zapobiegać ryzyku finansowemu, zwiększa szanse na odpowiednio wczesne rozpoznanie ewentualnych nieprawidłowości i umożliwia szybsze i sprawniejsze wykrywanie potencjalnych oszustw. Możliwe jest również promowanie ujawnienia dokładnych, wysokiej jakości oraz aktualnych informacji głównie finansowych na potrzeby wewnętrzne (sprawozdawczość zarządcza - dla zarządu i rady) oraz potrzeby zewnętrzne (sprawozdawczość finansowa - dla rynków i akcjonariuszy), a także dla nadzoru zewnętrznego i pozostałych interesariuszy.

\section{Zakończenie}

Postawiona na wstępie teza sugerowała, że obowiązki rad nadzorczych i komitetów audytu powielają się i nakładają, przez co nie wpływają korzystniej na realizację obowiązków w zakresie monitorowania oraz nadzorowania procesu generowania i badania sprawozdań finansowych. W świetle rozważań podjętych w opracowaniu należy stwierdzić, że teza ta została zweryfikowana negatywnie.

Aktywność i działalność komitetów audytu nie może w żaden sposób naruszać ustawowych uprawnień lub ograniczać kompetencji rady nadzorczej. Prawidłowe wykonywanie przez radę nadzorczą stałego nadzoru polega na podejmowaniu działań zgodnych z dedykowanymi regulacjami, statutem spółki, a także dobrymi praktykami handlowymi. Jednym ze szczególnych obowiązków rady nadzorczej jest obowiązek zapewnienia, aby sprawozdania finansowe oraz sprawozdania z działalności spółki spełniały wszelkie wymogi związane z obowiązkami informacyjnymi nałożonymi na JZP. Rada nadzorcza pozostaje zatem odpowiedzialna za nadzór nad zaprojektowaniem oraz wdrożeniem skutecznych systemów sprawozdawczości finansowej, które pozwolą rzetelnie i na czas informować interesariuszy o sytuacji finansowej i wynikach finansowych JZP. Zadania komitetu audytu wydają się być przy tym wtórne i uzupełniające, bowiem „ograniczają się” do opracowywania wniosków i argumentacji użytecznych dla rady przy podejmowaniu przez nią 
decyzji, jednak wcale nie oznacza to, że są nieprzydatne lub niepotrzebne. Wręcz przeciwnie - w dobie rosnącego znaczenia informacji oraz związanych z nimi wymogów dotyczących procesu sprawozdawczości finansowej rada nadzorcza jest szczególnie zainteresowana ciągłą oceną, stałym nadzorem i usprawnianiem działania spółki, aby zapewnić rzetelność generowanych informacji i prawidłowe wywiązanie się z nałożonych obowiązków sprawozdawczych, a pomocne przy tym stają się właśnie komitety audytu. Komitety audytu ułatwiają ocenę prawidłowości i rzetelności generowanych danych finansowych, dzięki czemu monitorowanie i nadzór nad obowiązkami informacyjnymi realizowany w jednostkach zainteresowania publicznego jest w stanie przyczynić się do podniesienia poziomu sprawozdawczości finansowej JZP, a tym samym wspomagać ich bezpieczne funkcjonowanie. Ustawowe nakładanie się pewnych zadań na obydwa organy oraz powielanie się ich kompetencji mimo wszystko występuje, zatem nie powinna następować dalsza ingerencja ustawodawcy w przedmiotowe uprawnienia i obowiązki tych podmiotów.

\section{Literatura}

Bednarek P., 2009, Rola komitetu audytu w tworzeniu skutecznego nadzoru korporacyjnego, Studia i Prace WNEiZ, nr 16, Szczecin.

Dobija D., 2010, Komitet audytu a nadzór nad biegłym rewidentem. Praktyka polskich spótek giełdowych, Zeszyty Teoretyczne Rachunkowości, nr 59, SKwP, Warszawa.

Dobija D., Koładkiewicz I., Cieślak I., Klimczak K., 2011, Komitety rad nadzorczych, Wolters Kluwer Business, Warszawa.

Dyrektywa Parlamentu Europejskiego i Rady 2014/56/UE z dnia 16 kwietnia 2014 r. zmieniająca dyrektywę 2006/43/WE w sprawie ustawowych badań rocznych sprawozdań finansowych i skonsolidowanych sprawozdań finansowych (Dz. Urz. UE z 27 maja 2014 r., L 158, s. 196 i n.).

Fila G., 2009, Funkcje komitetu audytu w statucie oraz aktach wewnętrznych spółki publicznej, Przegląd Corporate Governance, $\mathrm{nr}$ 4(20).

Gad J., 2016, Audyt zewnętrzny jako mechanizm nadzoru korporacyjnego, Zeszyty Naukowe Uniwersytetu Szczecińskiego, Finanse, Rynki Finansowe, Ubezpieczenia nr 4 (82), cz. 1, Wydawnictwo US, Szczecin.

Grzybek T., 2018, Obowiązki rady nadzorczej w spółce akcyjnej, https://grzybkowskiguzek.pl/przyklady/obowiazki-rady-nadzorczej-w-spolce-akcyjnej (13.05.2018).

Koziorowski L., 2017, Komitet audytu po nowemu, http://gessel.pl/publikacje/komitet-audytu-po-nowemu-2/(01.06.2017).

Marcinkowska M., 2004, Rola Komisji ds. Audytu we wspieraniu efektywnego nadzoru korporacyjnego, [w:] Ekonomiczne i społeczne problemy nadzoru korporacyjnego, red. S. Rudolf, Wyd. Uniwersytetu Łódzkiego, Łódź.

Mikulski R., 2017, Ważne zmiany w komitetach audytu, https://prnews.pl/robert-mikulski-wazne-zmiany-komitetach-audytu-430969 (08.11.2017).

Report and Recommendations of the Blue Ribbon Committee on Improving the Effectiveness of Corporate Audit Committees, 1999, New York Stock Exchange and National Association of Securities Dealers, New York. 
Rozporządzenie Parlamentu Europejskiego i Rady (UE) nr 537/2014 z dnia 16 kwietnia 2014 r. w sprawie szczegółowych wymogów dotyczących ustawowych badań sprawozdań finansowych jednostek interesu publicznego, uchylającego decyzję Komisji 2005/909/WE (Dz. Urz. UE z 27 maja 2914 r., L 158, s. 77 i n.).

Sawicki K., 2012, Wybrane problemy działania komitetu audytu w jednostkach zainteresowania publicznego, Zeszyty Teoretyczne Rachunkowości, nr 122, SKwP, Warszawa.

Sołtysiński S., Szajkowski A., Szumański A., Szwaja J., 2008, Kodeks spótek handlowych. Komentarz, t. III, C.H. Beck, Warszawa.

Ustawa z dnia 11 maja 2017 r. o biegłych rewidentach, firmach audytorskich oraz nadzorze publicznym uchylająca ustawę z dnia 7 maja 2009 r. o biegłych rewidentach i ich samorządzie, podmiotach uprawnionych do badania sprawozdań finansowych oraz o nadzorze publicznym (Dz.U. z 2017, poz. 1089).

Ustawa z dnia 15 września 2000 r. Kodeks spółek handlowych, Dz.U. z 2000, nr 94, poz. 1037.

Ustawa z dnia 29 września 1994 r. o rachunkowości, Dz.U. z 1994, nr 121, poz. 591.

Walińska E., Gad J., 2012, Odpowiedzialność rad nadzorczych za sprawozdania finansowe - doświadczenia polskich spótek publicznych, Zeszyty Teoretyczne Rachunkowości, nr 122, SKwP, Warszawa. 